\title{
Térbeli-társadalmi egyenlőtlenségek és újratermelésük az alapfokú oktatás hazai rendszerében
}

\section{Spatial-social inequalities and their reproduction in the Hungarian primary school system}

\author{
VELKEY GÁBOR
}

VELKEY Gábor: tudományos munkatárs, csoportvezető, Közgazdaság- és Regionális Tudományi Kutatóközpont, Regionális Kutatások Intézete; 5600 Békéscsaba, Szabó Dezső utca 42.; velkey.gabor@krtk.mta.hu; http://orcid.org/0000-0002-4677-0743

KULCSSZAVAK: oktatási rendszer; társadalmi-térbeli egyenlőtlenségek; oktatási szelekció; intézményi szegregáció

ABSZTRAKT: A tanulmányban a társadalmi-térbeli egyenlőtlenségek alakulását és újratermelését az oktatás - tanulás - képzés - nevelés rendszerén keresztül vizsgálom. Kiemelt figyelmet fordítok az állam szerepére és szerepkörváltozásainak következményeire. Munkám során tudatosan „alulnézetből” közelítek, ahogy a jelenségek érzékelhetővé válnak az emberek számára, és ahogy helyben alakítják tevékenységüket. Megközelítésem szerint ugyanis, a globális gazdaság térbeli leképeződései, a regionális és nemzeti intézményi keretek, gyakorlatok, illetve a helyi-térségi társadalmi hatások egymással szorosan összefonódva jelennek meg a konkrét szereplők konkrét helyekhez kötődő mindennapi cselekvéseiben. Elemzésem hátterét 2014-2018 között, három magyarországi településen folytatott empirikus kutatás tapasztalatai adják. Feltárva a legfontosabb okokat és következményeket az iskolai szelekció és szegregáció jelenségét igyekszem megérteni. Munkám során az intézményes oktatást bürokratikusan szervezett nagyrendszerként értelmezem, melyben az állam az általa elfogadott szabályozókon keresztül, az általa irányított mechanizmusok révén osztja el a szolgáltatásokat. Ezek az igénybe vevők számára „elérhető szolgáltatásként” jelennek meg, de a különböző helyzetü egyének és csoportok számára eltérő mintázatokat mutatnak. Lefebvre társadalmi tér koncepcióját és Soja térbeliség értelmezését felhasználva az „elérhető szolgáltatásokon” belül elkülönítem a „felkínált” és az emberek számára „ténylegesen igénybe vehető” szolgáltatásokat. Ezt a differenciált megközelítést alkalmazva értelmezem az állam, a helyi hatalom, a helyi elitek szerepét az oktatási szolgáltatások alakításában és az iskolai szelekció, szegregáció egyre markánsabban megjelenő folyamataiban. A szelekcióban, szegregációban a tanulók családi háttere, társadalmi státusza, szociális helyzete és származása döntő szerepet játszik, nagyban hozzájárulva a társadalmi és térbeli egyenlőtlenségek újratermeléséhez, növekedéséhez.

Gábor VELKEY: research fellow, head of unit, Institute for Regional Studies, Centre for Economic and Regional Studies; Szabó Dezső u. 42., H-5600 Békéscsaba, Hungary; velkey.gabor@krtk.mta.hu; http://orcid.org/0000-0002-4677-0743

KEYWORDS: education system; spatial and education inequalities; selection; segregation

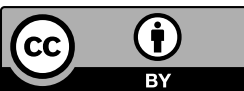


ABSTRACT: In the study, I examine the development and reproduction of socio-spatial inequalities through the system of education, learning and training, with particular emphasis on the role of the state (central and local) and the consequences of changes in its roles. In my work, I consciously approach phenomena from a "bottom-up" perspective as they become perceptible to people and their communities and shape and influence their activities locally. Thus, in my analysis, spatial representations of the world economy, regional and national institutional frameworks, practices and local-regional social influences are closely intertwined with the everyday behaviour of certain actors in certain places. The background to my analyses is the experience of empirical research in three Hungarian settlements between 2014 and 2018, in which I tried to investigate the phenomena of school selection and pupil segregation and their main causes and consequences.

In my work, I interpret institutional education as a large, bureaucratically organised system in which the state distributes services through the regulatory authorities it accepts and through the mechanisms it controls and supervises, which consequently appear to users as "accessible services", but with different patterns for individuals and groups in different situations. Using the concept of Lefebvre's social space and the interpretation of Soja's spatiality, I distinguish within the (theoretically) "available services" between services that are "offered" and those that are "actually available" to people. With this differentiated approach, I interpret the role of the state, local government and local elites in shaping educational provision and in the ever-increasing processes of pupil selection and segregation, in which the family background, social and economic status and ethnicity of pupils play a crucial role and contribute significantly to the reproduction and growth of social and spatial inequalities.

\section{Bevezetés}

A társadalmi-térbeli egyenlőtlenségek a tartós leszakadás, marginalizálódás erősödésével, a kapcsolódó egyre súlyosabb szociális és demográfiai problémák halmozódásával napjainkra nemcsak a tudományos, hanem a társadalompolitikai diskurzusokban is az egyik leggyakrabban hivatkozott témakörré váltak. A tartóssá váló és mélyülő egyenlőtlenségek okait és mechanizmusait elemző nemzetközi és hazai tudományos megközelítések mellett egyre szélesebb körben jelennek meg a konkrét beavatkozást sürgető közösségi kezdeményezések, civil akciók - válaszra, lépésre kényszerítve ezzel a politikum szereplőit és az államot is.

Az egyenlőtlenségek értelmezésében az alakító folyamatok komplexitására hivatkozások, a gazdaságon túli jelenségek, köztük a társadalmi reprodukció mechanizmusainak, intézményi kereteinek és napi gyakorlatainak hangsúlyozása, illetve azok helyi-térségi viszonyokba ágyazottsága jelentenek új irányt (Hadjimichalis, Hudson 2014; Lang et al. 2015; Soja 2010). E megközelítések alapján a globális gazdaság térbeli leképeződései, a regionális és nemzeti intézményi keretek, gyakorlatok, illetve a helyi-térségi társadalmi hatások egymással szorosan összefonódva jelennek meg a konkrét szereplők konkrét helyekhez kötődő mindennapi cselekvéseiben és az azokat alakító viszonyokban (Hudson 2016; Peck 2016). A lokális terek jelenségei egyrészt a helyi kereteken túlmutató hierarchiák, hálózatok, kapcsolatok részeként és komplex leképeződéseként értelmezhetők, másrészt vizsgálatuk lehetőséget teremt a makrofolyamatok mindennapi életet befolyásoló hatásainak, a társadalmi szereplők konkrét válaszainak, a kapcsolódó konflik- 
tusoknak és intézményi keretekre történő visszahatásaiknak megértésére. Elemzésem során ezért tudatosan „alulnézetből” közelítem a jelenségeket, ahogy azok érzékelhetővé válnak az emberek és közösségeik számára, és ahogy helyben alakítják, befolyásolják tevékenységüket.

A közszolgáltatások kiemelt szerepet töltenek be a társadalmi reprodukció intézményes struktúrái között, így a társadalmi-térbeli egyenlőtlenségek alakításában, újratermelésében is. Különösen igaz e megállapítás az oktatás - tanulás képzés - nevelés rendszerére, melynek megszervezésében és müködtetésében az államnak meghatározó szerepe van. A tanulmány egy 2014-2018 között végzett empirikus kutatás eredményeit összefoglalva az oktatás - tanulás -képzés - nevelés rendszerén keresztül közelíti a térbeli-társadalmi egyenlőtlenségek alakulását, újratermelését, kiemelt figyelmet fordítva a központi és helyi állam szerepére, illetve szerepkör-változásainak következményeire.

Az elemzést megalapozó kutatás három mintaterületen, kvalitatív módszerek segítségével vizsgálta az alapfokú oktatás intézményrendszerét, az iskolaválasztás folyamatát és jellemzőit az iskolakezdés időszakában, illetve a négy- és hatosztályos gimnáziumokban, a szelekciót erősítő és gyengítő tényezőket, az iskolai szegregáció alakulását, valamint az iskolákon belüli szelekció jellemzőit és következményeit. A vizsgálat kiterjedt az iskolai teljesítmények mérhető adataira (kompetenciamérések), a tanulók társadalmi helyzetére, az akadályozottság következményeire, a tanulási képességekben, figyelemben, magatartásban megfigyelhető zavarokra és a kulturális, etnikai jellemzőkre, különbségekre. Mindhárom mintatelepülésen a fenntartók képviselőivel, települési vezetőkkel, intézményi dolgozókkal, pedagógiai szakszolgálatok szakembereivel, továbbá a szolgáltatásokat igénybe vevő gyerekekkel készített interjúk, egy-egy intézményben pedig tanárokkal és szülőkkel készített fókuszcsoportos interjúk, illetve az iskolák legfontosabb dokumentumainak és az országos kompetenciamérés telephelyi adatainak elemzése alapozták meg az empirikus kutatásokat.

Bár az elemzés hátterét jelentő empirikus kutatás 2014-2018 között folyt, én lényegesen hosszabb időtávot átfogva vizsgálom az oktatási rendszer működését és szerepét a társadalmi egyenlőtlenségek újratermelésében. A hosszabb időtáv és az a tény, hogy ezalatt az oktatási rendszert alapjaiban megváltoztató több radikális átalakítás is történt Magyarországon, teszi lehetővé, hogy értelmezzük az állam szerepének és szerepkör-változásainak következményeit, illetve megértsük azokat a mechanizmusokat, melyek e változások hatására formálták és napjainkban is formálják az egyes emberek és csoportjaik lehetőségeit az oktatáshoz, oktatási intézményekhez és szolgáltatásokhoz történő hozzáférésben.

\section{Megközelítés, elméleti háttér}

A kötelező népoktatás bevezetése óta, vagyis Európa legtöbb országában legalább bő száz éve, az alapfokú oktatás az állam egyik legfontosabb intézményes köz- 
szolgáltatása. Az igénybe vevők felől (alulnézetből) közelítve ez azt jelenti, hogy a tanulás intézményes, szervezett formáinak kialakításában és működtetésében az állam meghatározó szerepet tölt be, amiből értelemszerűen következik, hogy az oktatási rendszerek szervezésében a bürokratikus koordináció és a közfinanszírozás a domináns mechanizmus. Ez annak ellenére igaz, hogy az egyes országok, országcsoportok lényegesen eltérő társadalomfejlődés és tradíciók után jutottak el a mai, az állami mellett - különböző arányban és formában - magán (piaci) szolgáltatásokat is lehetővé tevő oktatási rendszereikhez. Az egyes országok oktatási rendszerei azonban nemcsak az állami és magánszolgáltatások arányában, illetve az ezekkel kapcsolatos szabályozásban, hanem az oktatási rendszerek müködését alapvetően meghatározó kérdésekben is lényeges eltéréseket mutatnak:

- a tankötelezettség meghatározásában,

- az állam központi és területi szervei közötti feladatmegosztásban, az önkormányzatok szerepében és felelősségében,

- az intézményi szolgáltatások kiterjedtségében; az alapszolgáltatások, egyéb szakmai szolgáltatások és a kapcsolódó kiegészítő (szociális, mentális, közösségi, egészségügyi, étkeztetési) szolgáltatások körében,

- a magán-, civil és egyházi szolgáltatók lehetőségeiben,

- az intézményrendszer szerkezetében (méret, elhelyezkedés, tagoltság) és finanszírozásában (köz- és magánforrások, központi és helyi adóbevételek, piaci kiegészítő források),

- a szakmai és társadalmi kontroll megszervezésében, az érintett szereplők (pedagógusok, szülők, diákok, helyi közösségek, gazdasági szereplők) döntésekbe történő bevonásában és annak intézményesítésében.

Az intézményes oktatás tehát bürokratikusan szervezett nagyrendszer, melyben az állam az általa elfogadott szabályozókon keresztül és az általa irányított (felügyelt) mechanizmusok révén szervezi és elosztja a szolgáltatásokat, amelyek így az igénybe vevők számára „elérhető szolgáltatásként” jelennek meg. Az elérhető szolgáltatások pedig nemcsak térhez és időhöz kötöttek, hanem eltérő mintázatot is mutatnak a különböző helyzetü egyének és csoportok számára. Lefebvre (1991) társadalmitér-koncepciója és Soja (1996) térbeliségértelmezése - megítélésem szerint - alkalmas elméleti keretet jelent ezen eltérő mintázatok értelmezésére.

Az intézményes oktatást nyújtó szolgáltatások konkrét helyeken lévő szolgáltató egységeket jelentenek. Ezekhez egyúttal képzetek, koncepciók, konstrukciók is kapcsolódnak, amelyek valamiként lecsapódnak az egyes emberekben és csoportjaikban. Másként fogalmazva, valahogyan megjelennek, láthatóvá, érzékelhetővé válnak számukra. Az oktatási szolgáltatások esetén is beszélhetünk tehát a tér termeléséről: elkülöníthetjük az érzékelt teret (első tér), az elgondolt teret (második tér) és a megélt teret (harmadik tér) (Lefebvre 1991; Soja 1996). A térbeliség e hármas, dinamikus felfogását (Berki 2015) továbbgondolva, az objektív, mérhető és elvileg mindenki számára azonos módon érzékelhető tér analógiájaként értelmezett „elérhető szolgáltatásokon” belül megkülönböztethetjük az 
igénybe vevők számára valódi lehetőségeket jelentő „felkínált szolgáltatások terét", valamint ennek konkrét megjelenését az igénybe vevőkben, vagyis a szolgáltatásoknak azt a körét (terét), amely számukra „egyszerre ismert és ténylegesen igénybe is vehető".

Az igénybe vevő számára ugyanis nem a fizikai valóságában megjelenő oktatási intézmény vagy a kilométerben mérhető távolság az érdekes, hanem az elérhetőség valóságos lehetőségei, amit az úthálózat, a tömegközlekedés, a kollégiumi férőhelyek is befolyásolnak. De önmagában egy fizikailag elérhető iskolaépület sem jelent reális (csak formális) szolgáltatási lehetőséget, ha annak képzési profilja, programja, felvételi eljárási gyakorlata kizárja, korlátozza a szolgáltatást keresők valamely csoportját. Sőt, külső korlátok, akadályok nélkül is lehetnek olyan szolgáltatások, amelyek valamilyen belső indíttatás, szemlélet, esetleg tájékozatlanság, kishitűség miatt fel sem merülnek valakik számára.

Az oktatási szolgáltatások terét egyrészt közvetlenül, az oktatási rendszeren keresztül, az intézmények térbeli elhelyez(ked)ésével, a képzési profilok, irányok meghatározásával, a hozzáférés, működés szabályozásával, másrészt pedig közvetve, az elérhetőséget befolyásoló egyéb feltételek biztosítása révén (úthálózat, tömegközlekedés stb.) alapvetően az állam kínálja fel. Mindkét összetevő esetében fontos kiemelni, hogy a szolgáltatások felkínálása mindig „valakik” számára történik. A „felkínálás” önmagában hordozza a kedvezményezettekre vonatkozó szándékot; tudatosan célozhat tágabb vagy szűkebb (meghatározott) kört. Az állam tehát nemcsak létrehozza, hanem egyúttal az igénybe vevők számára értelmezi is (konstruálja) az oktatás szolgáltatási terét. A térnek ez az értelmezése állami döntésekben nyilvánul meg, ezért az állami döntéshozatal folyamatában, vagyis a hatalmi-politikai mező működésében ragadhatók meg a felkínált szolgáltatások körét formáló tényezők.

A felkínált szolgáltatások alakítása, módosítása az intézményes oktatás esetében közvetlenül az oktatáspolitikán, közvetve pedig az egyéb politikákon (társadalompolitika, településpolitika, gazdaságpolitika, költségvetési politika stb.) keresztül történhet, mely döntéseknek a hatás- és feladatkörök elosztásától függően lehetnek központi szinten és decentralizáltan érvényesülő elemei.

A különböző érdekcsoportok, közösségek - kihasználva a hatalmi politikai mező által kínált lehetőségeket - az általuk igényelt szolgáltatások elérését célozva próbálják befolyásolni a rendszer működését, vagyis igényeiknek megfelelő irányba alakítani az oktatási szolgáltatások (számukra) felkínált terét. Ilyen kezdeményezésnek tekinthetők a hiányzó vagy korlátozottan rendelkezésre álló szolgáltatások kikényszerítésére irányuló törekvések, akár közfinanszírozott formában, akár magánszolgáltatások megszervezésével, vagy helyi szinten az adott képzési hálózat egészét, illetve egyes részegységeit érintő konkrét döntések befolyásolására irányuló akciók (tagozatok, speciális programok, kiegészítő szolgáltatások indítása, infrastruktúra korszerüsítése, személyi feltételek javítása, kapcsolódó szolgáltatások - büfé, étkeztetés, sport és közösségi programok - fejlesztése). 
Az oktatási rendszerekbe illeszkedő (piaci) magánszolgáltatási elemek aránya és formái így szintén rendkívül sokszínűek lehetnek, miként létrejöttük háttere is. Egészen másként alakul a magán- és állami (önkormányzati) oktatási szolgáltatások egymásra épülése, közös (állami) oktatási rendszerbe illeszkedése a tisztán piaci szolgáltatási, az egyházi szolgáltatási és az autonóm helyi közösségi (települési) szolgáltatási tradíciókra alapozódó rendszerekben, vagy a magánés egyházi szolgáltatásokat kizáró (erősen korlátozó) államosított (államszocialista) szolgáltatási előzmények esetén. Amikor az oktatási szolgáltatások felkínált teréről beszélünk, az összes felkínált szolgáltatási elemet beleértjük, így a differenciáltan elérhető magánszolgáltatások valamennyi típusát, a magániskolától kezdve, az alapítványi képzési formákon, fizetett szervezett tanfolyamokon, magántanulói státuszt kihasználó formális vagy informálisan szervezett képzéseken át egészen a szülők által megvásárolt egyéni különórákig.

Az oktatási szolgáltatások felkínált tere - „második térként” - „a valóságot interpretálja a térbeliség reprezentációinak segítségével" (Berki 2014, 96.) a fogyasztók számára. Másként megfogalmazva: ez a hatalom által formált és irányított tér. Az állam jogszabályokban, koncepciókban, tervekben fogalmazza meg az oktatási rendszerrel kapcsolatos céljait, valódi arcát azonban az eltérő helyzetű emberek számára biztosított reális lehetőségekkel teszi láthatóvá. A térben élő ember pedig igazodik ezekhez a lehetőségekhez: saját maga számára lefordítja, értelmezi azokat. A szolgáltatást igénybe vevők saját megközelítésük, mentalitásuk, helyzetük alapján a felkínált szolgáltatások eltérő mintázatait látják; a megélt tér (harmadik tér) középpontjában a mindennapjait „itt és most” átél” szubjektum áll (Carman 1999). Fizikailag benne élve a térben, annak az általa értelmezhető (számára konstruált, felkínált) szegmensei alakítják cselekedeteit, döntéseit, választásait, melyek így a külső kényszerekhez történő igazodásnak, a saját határok értelmezésének és az e tényezőkhöz viszonyulásnak (beletörődés, elfogadás, határok tágítása) az egyvelege. $\mathrm{E}$ döntései eredményeként éli meg a szubjektum a mindennapjait, így azon részleteket is, melyek kapcsolatban vannak az oktatási rendszerrel: a megélt tér a mindennapokban itt és most élő szubjektum számára a realitás maga.

\section{Fő kutatási kérdések, vizsgálati keretek}

A kutatás a mindennapjaikat élő emberek lokális terekben meghozott konkrét döntései alapján - „alulnézetből” - közelíti az oktatási rendszert. Az emberek döntéseiből próbál következtetni a számukra „felkínált” lehetőségekre, vagyis a hatalom által formált és irányított térre (második tér) és annak jellemzőire, felépítésére, működésére; vizsgálja:

- a központi és helyi hatalom szerepét, befolyását, a különböző érdekcsoportok lehetőségeit a felkínált szolgáltatások alakításában; 
- azt, hogy kiknek, hol, milyen tartalmú és színvonalú szolgáltatást kínálnak fel, és hogyan történik a szolgáltatást igénylők közül az igénybe vevők kiválasztása;

- azt, hogy a közfinanszírozott szolgáltatások mennyiben fedik le az igényeket, megjelennek-e (és ha igen, milyen finanszírozási háttérrel) a magán-, egyházi vagy egyéb közösségi szolgáltatások (intézményesült vagy nem intézményesült formában).

Az elérhető és felkínált oktatási szolgáltatások tere csak helyben ragadható meg, még ha a lokális terek magukon viselik is a helyi kereteken túlmutató hierarchiák, hálózatok hatásait: utóbbiak ugyanis a konkrét helyi viszonyokon, adottságokon, örökségeken, a lokális társadalom jellemzőin (összetétel, egyenlőtlenségek, együttműködések, megosztottságok) és a helyi hatalom működésén (érdekkörök, aktivitás) átszűrve jelennek meg. A „hely” fontos jellemzője, hogy másként jelenhet meg a különböző helyzetü, kultúrájú emberek és csoportok számára. A három kiválasztott mintatelepülésen közös vonás a cigány népesség jelenléte. Térbeli elhelyezkedésük, települési kapcsolataik és méretük alapján azonban lényegesen eltérő jellemzőkkel írhatók le. Az iskolai szelekció és szegregáció alakulásában a szakirodalom alapján megkérdőjelezhetetlen az etnikai különbségek és azok helyi társadalmi viszonyokat alakító szerepének, továbbá az „oktatási piac" egyéb jellemzőinek (helyi iskolák száma, jellegzetességeik, adottságaik, környező településeken elérhető szolgáltatások) fontossága (Havas, Kemény, Liskó 2002; Kertesi, Kézdi 2014; Ladányi 2009; Fejes, Szűcs 2018; Zolnay 2018). Az esettanulmányok helyszínének kiválasztásakor e szempontok mindegyikét igyekeztem érvényesíteni, így a vizsgált települések egyike központi szerepkörrel rendelkező, hagyományos ipari övezetben fekvő kisváros (X), a másik egy hátrányos helyzetű, határ menti zónában fekvő kisebb város (Y), melynek környezetében található az adott megye egyik legfontosabb, széles körü közszolgáltatásokkal rendelkező városa, a harmadik pedig e kisváros térségébe tartozó periférikus fekvésű, kedvezőtlen közlekedési kapcsolatokkal jellemezhető község (Z). A települések lélekszáma, húsz-, tíz- és egyezer fő körüli, a 2011-es népszámlálási adatok alapján a magukat cigány/roma nemzetiségűnek nevezők aránya sorban 15, 10 és $30 \%$, a foglalkoztatottak nélküli háztartások aránya pedig 40,50 és $60 \%$ körüli értéket mutat.

Az elmúlt közel fél évszázadban Magyarországon három, alapvetően eltérő oktatási rendszert működtetett az állam. Az államszocializmus hierarchikusan felépített, mégis részben decentralizált „tanácsi” oktatási rendszerét 1990 után egy központi keretszabályozásra, önkormányzati fenntartásra és finanszírozási felelősségre, továbbá széles körü intézményi autonómiára alapozott, szélsőségesen decentralizált rendszer követte, melyet 2011-től egy finanszírozásában, fenntartásában, irányításában és ellenőrzésében is egységesített, végletesen centralizált állami rendszer váltott fel. 
Az elemzés hátterét jelentő empirikus kutatásaim mindhárom mintaterületen 2014-2018 között folytak, ám ennél hosszabb időtávot átfogva, a 2011. évi változások előtti időszak jellemzőit is figyelembe véve vizsgálom az oktatási rendszer működését és szerepét a társadalmi egyenlőtlenségek alakulásában, újratermelésében. $E$ hosszabb időtáv és a rendszer minden lényeges elemét (finanszírozás, fenntartás, irányítás, szabályozás, ellenőrzés, társadalmi kontroll) érintő 2011. évi radikális átalakítás teszi igazán lehetővé, hogy értelmezzük az állam szerepének és szerepkör-változásainak következményeit, továbbá azokat a mechanizmusokat, amelyek a helyi társadalmi viszonyokat alakítva meghatározzák az egyes emberek és csoportjaik lehetőségeit, esélyeit az oktatási rendszerben történő sikeres előrehaladásra.

A társadalmi-térbeli egyenlőtlenségek újratermelése az oktatási rendszer esetében ugyanis - értelmezésünk szerint - az előrehaladási esélyek alakulásában ragadható meg. Abban tehát, hogy az érintettek számára lakóhelyüktől és jövedelmi helyzetüktől, társadalmi státuszuktól, családi hátterüktől, származásuktól, kapcsolatrendszerüktől függetlenül biztosított-e a lehetősége annak, hogy képességeiket, adottságaikat figyelembe véve magas szintű teljesítményt érjenek el. Másként fogalmazva: kimutathatók-e érdemi különbségek a különböző helyeken élo", eltérő társadalmi helyzetű egyének számára elérhető és felkínált szolgáltatások körében és minőségében. Vagyis mennyiben/miben térnek el az elérhető (első) és felkínált (második) szolgáltatások terei. És végül, ezek alapján hogyan „választanak iskolát” (harmadik tér) a különböző helyeken élő, eltérő társadalmi helyzetü csoportok tagjai.

A tanulók az intézményes szolgáltatásokat szervezett keretek között iskolákban, azokon belül pedig tanulócsoportokban veszik igénybe. A szolgáltatásban megfigyelhető különbségek így lehetnek intézmények közöttiek és intézményen belüliek. Szinte minden ország oktatási rendszerében létezik olyan szelekciós mechanizmus, mely különböző intézménytípusokat kínál fel a tanulók számára, választásra is kényszerítve őket. E szelekció abban az értelemben mindenhol általánosnak tekinthető, hogy az összes tanulót érinti valamikor. Az országok többségében azonban nem 14 éves korban vagy azt megelőzően (miként hazánkban), hanem később, és nem egy, hanem több lépésben kerül rá sor. Ráadásul, többnyire biztosított a téves vagy hibás választás korrekciójának lehetősége is. A középiskolai intézménytípus kiválasztásában mindenhol fontos szempont a tanulási teljesítmény, ám azokban az országokban, ahol például a felsőoktatásba történő továbblépésre a középfokú szakképzés is széles körü lehetőséget biztosít, e döntés szerepe lényegesen kisebb.

Magyarországon a szelekció a középiskolába történő belépéssel (14 éves korra) minden tanuló esetében megtörténik. És bár az átjárhatóságra hivatkozva voltak kezdeményezések arra, hogy akár a képzési szint, akár a szakmai kimenetel tekintetében lehetőség legyen a választás korrigálására, a szakirodalomban nincs vita arról, hogy a magyar rendszer túl korán és kellő megalapozottság nélkül 
kényszeríti ki a tanulók intézményváltását (pályaválasztását), továbbá kevés lehetőséget biztosít a korrekcióra. Ebből egyértelműen következik, hogy a középiskolai továbbtanulásban Magyarországon a tanulási eredményeknek döntő szerepe van (Csapó 2008; Herman 2008; Velkey 2013), amit megerősítenek a nemzetközi összehasonlító vizsgálatok is. A 2015-ös PISA-mérés szerint (mely a 15 éves tanulók teljesítményét méri, tehát középiskolába lépés után történik) az iskolák közötti különbségek természettudományi eredmények szórását magyarázó ereje Magyarország esetében kiemelkedően magas (Radó 2018). Mindez arra hívja fel a figyelmet, hogy a magyar oktatási rendszer tanulói teljesítményben megfigyelhető érdemi egyenlőtlenségei 14 éves kor előtt, vagyis az alapfokú képzési rendszerben alapozódnak meg. Kutatásunk során ezért az alapfokú oktatási szolgáltatásokat vizsgáljuk.

\section{Előzmények - A fokozatosan erősödő általános iskolai szelekció és szegregáció okai, összetevői és következményei 2011 előtt}

A 2011 előtti folyamatok jellemzőinek áttekintése nélkülözhetetlen az esettanulmányokban feltárt jelenségek értelmezéséhez, ezért ezt az időszakot - korábbi kutatásaimra és a szakirodalomra támaszkodva - az országosan érvényesülő legfontosabb, iskolaválasztást befolyásoló tendenciákra koncentrálva foglalom össze.

A rendszerváltás utáni időszak (általános iskolai) „,beiskolázási” gyakorlatát az 1990-es évek elején az államszocializmus alulnézetből változatlan, egységes, előírt körzeti ellátási logikát követő intézményszervezési és intézményhasználati tradícióinak továbbélése jellemezte. A jogszabályokban meglehetősen hamar (1985) megjelent a szabad iskolaválasztás lehetősége, ám ennek ellenére jellemző maradt a körzeti iskolába történő beiratkozás. Az iskolák tanulóinak társadalmi összetétele nagyrészt követte a társadalom térbeli elrendeződését: az iskolai szegregáció azokban a terekben jelent meg, ahol a település vagy településrész is szegregátum volt. Az elemzések egyértelműen kiemelik, hogy e szegregátumok iskolái, iskolai telephelyei a tárgyi, szakmai feltételek és egyéb szolgáltatások tekintetében már az 1980-as években is alacsonyabb színvonalon teljesítettek (Forray 1986), ami a következő két évtizedben erősödött.

Az 1980-as évek elejének hazai oktatási rendszerét elemezve egy vizsgálat országosan mindösszesen százötven olyan tanulócsoportot említ, ahol többségben vannak a cigány tanulók (Havas, Kemény, Liskó 2002). 2005-re a helyzet radikálisan megváltozott: miközben a cigány tanulók aránya közel kétszeresre nőtt, a homogén cigány osztályok száma a korábbi érték nyolcszorosára emelkedett, és ennek háromszorosa volt azoknak az osztályoknak a száma, ahol többségben voltak a cigány tanulók (Havas, Liskó 2006). Ráadásul, a tudatos elkülönítés burkolt technikájaként egyre szélesebb körben vált jellemzővé a nehezen kezelhetö, fóképp cigány tanulók kisegítő iskolákba szorítása is (Ladányi 2009). A szakiroda- 
lom által tehát már az 1990-es évek elején feltárt erősödő szegregáció mellett egyre szélesebb körben érvényesült az intézményesített belső szelekció is. A több párhuzamos osztállyal müködő iskolákban a szakrendszerủ oktatás (felső tagozat) megkezdésekor újraszervezett osztályokba a tanulási teljesítmény, érdeklődés, tehetség alapján sorolták be a tanulókat (tagozatok). Ez egyszerre szolgálta a tanulók előmenetelében érdekelt szülők igényeit és az iskolák szakmai presztízsét segítő pedagógiai innovációkat. Ráadásul, összhangban volt a korábbi évtizedek deklaráltan egyenlősítő oktatáspolitikáját háttérbe szorító, decentralizációra, piacosításra hivatkozó késő kádárizmus oktatáspolitikájával (Kovai, Neumann 2015), amely a korábbi „egységesítéssel” szemben tudatosan támogatta a pluralizmust, az autonómiát és az alternativitást. A körzeti iskola választását természetesnek tekintő szemlélet éppen az alternatív, kísérleti pedagógiai innovációkra, tehetséggondozó programokra hivatkozva kezdett előbb szűkebb, majd egyre tágabb körben megkérdőjeleződni. Ebben - az 1990-es évek közepétől - három, egymással szorosan összefüggő tényező játszott meghatározó szerepet:

- a demográfiai folyamatokból is következő többletkapacitások tartós fennmaradása,

- a szolgáltatások gyorsuló differenciálódása

- és a szülői szemlélet változása.

\section{Az általános iskolai férőhelyek és a tanulói létszám alakulása}

Az 1980-as évek elején általános iskolába lépő nagy létszámú évfolyamokhoz igazított képzési kapacitások fenntarthatatlanságával 1990-es évek első felében szembesülő önkormányzatok - pénzügyi ösztönzők hatására, eltérő intenzitással - hozzáfogtak a felesleges férőhelyek kivezetéséhez. A tanulók létszámának csökkenését kis késéssel, ütemesen követte a tanulócsoportok számának fogyása, miközben az iskolák számának csökkenési üteme mindvégig elmaradt attól. Ez két okra vezethető vissza: egyrészt az egy iskolát működtető önkormányzatok településpolitikai okok miatt erőn felüli áldozatokat vállalva próbálták megtartani iskolájukat, ${ }^{1}$ másrészt az önkormányzatok megfelelő beiskolázási szabályozókkal érdemi viták nélkül is képesek voltak a tanulócsoportok számát a csökkenő tanulószámhoz igazítani, de nehezen vállalták a súlyos konfliktusokat jelentő iskolabezárásokat.

Az iskolák számában 2007-2008-ban hullámszerü csökkenést figyelhetünk meg, melyet az elemzések a kistérségi társulások pénzügyi támogatásához és adminisztratív szabályaihoz kapcsolódó szigorításokkal összefüggő iskola-összevonásokkal, illetve a tovább romló költségvetési helyzet miatt erősödő racionalizálási kényszerrel magyaráznak (Hajdú, Hermann, Horn, Varga 2016; Radó 2018). Megítélésem szerint azonban, fontos szerepe volt ebben a helyi konfliktuskezelési gyakorlatban érzékelhető változásoknak is, mely összefügg a megváltozott országos politikai környezettel, és a korábbi években már szinte minden nagyobb várost 
elérő, súlyosabb konfliktusok nélkül lezajló iskola- és intézmény-összevonási hullámmal is. ${ }^{2}$

A túlkínálat kialakulásában kezdettől fogva szerepet játszottak a rendszerváltás után létrehozott új egyházi általános iskolák. Bár számuk és arányuk 2010-ig nem volt jelentős, ${ }^{3}$ és főképp a nagyobb városokban jöttek létre, szerepük mégis kiemelendő: a kedvezőbb finanszírozási feltételek (kiegészítő normatíva) és a körzeti ellátási kötelezettség hiánya miatt ugyanis a gyermekekért folyó versenyben egyértelmű előnyt élveztek. Számuk lassú növekedésében e két tényező játszotta a legfontosabb szerepet. Az önkormányzatukkal konfliktusba kerülő iskolák, illetve a finanszírozási problémák miatt kényszerhelyzetbe kerülő önkormányzatok kezdeményezték leggyakrabban az iskola egyházi fenntartásba adását (Velkey 2013).

Összefoglalva elmondható tehát, hogy az 1990-es évek elejére elsősorban a demográfiai változások következtében kialakuló általános iskolai többletkapacitások az ország szinte minden szegletében tartósan fennmaradtak, lehetővé téve ezzel a tanulók iskolák és települések közötti mozgását, vándorlását már az általános iskola megkezdésének időszakában.

\section{A szolgáltatások gyorsuló differenciálódása}

A szolgáltatások differenciálódása a fenntartó önkormányzatok költségvetési pozíciójával függ össze: az 1990-es évek közepétől hullámzóan, de folyamatosan romló, majd a 2000-es évek második felétől drámaivá váló helyzet felgyorsította a folyamatot. A kedvezőtlenebb helyzetű, saját bevételekkel alig rendelkező kisebb települések számára egyre nehezebbé vált az iskolák fenntartási költségeit csökkenő arányban fedező állami normatíva ${ }^{4}$ saját forrásokkal (fenntartói hozzájárulás) történő kiegészítése. Iskoláik fenntartását tovább nehezítette az alacsony gyermeklétszámból következő magasabb fajlagos költség, mely egyszerre vezetett az oktatási infrastruktúra és eszközállomány leromlásához, a szükséges szakemberek biztosításának nehézségeihez, a felzárkóztatás és tehetséggondozás feltételeinek ellehetetlenüléséhez.

Ez a kézzel fogható, mindennapokban is érzékelhető folyamat lényegében visszatartotta mindazokat a helyi iskola választásától (illetve ösztönözte az iskola rendhagyó szerkezetű gimnáziumok felé történő elhagyására a negyedik vagy hatodik évfolyam után), akik számára megvolt a lehetőség arra, hogy gyermeküket máshova járassák. E jelenséget ugyanakkor érdemben befolyásolták a helyi társadalom belső viszonyai, például az erős helyi szolidaritás, az összetartó közösség, a helyi elit példamutatása (akár a helyben maradás, akár az eljárás mellett), a helyi társadalom megosztottsága, családok közötti konfliktusok, etnikai feszültségek.

A nagyobb községeket és kisebb városokat a romló tendencia a magasabb gyermeklétszámból következő nagyobb személyzet és racionálisabb csoportszervezés lehetősége miatt kevésbé sújtotta, ráadásul a magasabb helyi adóbevételek 
eleve nagyobb költségvetési mozgásteret biztosítottak számukra. A normatív finanszírozásból következő pénzügyi érdekeltség pedig nyitottá tette őket a „bejáró tanulók" 5 fogadására is, hiszen a már elindított osztályok feltöltése kívülről jött tanulókkal többletnormatívát hozott. E települések tehát örömmel fogadták a romló feltételek elől „menekülő”, kistelepülésen lakó, jellemzően mobilabb, magasabb státuszú, a tanulást, tudást értékelő, gyermekük iskolai előmenetelére érzékeny, így beilleszkedési konfliktust sem okozó családok bejáró gyermekeit. A nagyobb városok, megyeszékhelyek gyermekelszívó hatása azonban egyértelmüen erősebb volt, így a településszerkezeti jellemzők, közlekedési kapcsolatok érdemben befolyásolták a tanulók bejárási irányait. A nagyobb városok szélesebb körű szolgáltatási kínálata, a tartósan meglévő többletkapacitások és az e településeken jellemző, körzeti ellátási kötelezettséggel nem terhelt egyházi vagy magániskolák már az általános iskola megkezdésekor ${ }^{6}$ éles versenyhelyzetet teremtettek, melyet a szintén nagyobb városokban müködő, többségükben egyházi fenntartású, rendhagyó szerkezetű (nyolc- és hatosztályos) gimnáziumok tovább erősítettek. A verseny okát a többletkapacitások, lehetőségét pedig a szabad intézményválasztás alapozta meg: ráadásul két párhuzamosan zajló, mégis egy irányba mutató versenyről beszélhetünk. Élesedő verseny alakult ki egyrészt a szülők (tanulók) között a magasabb színvonalú ellátáshoz való hozzáférésért, másrészt az intézmények között a gyermekek beiskolázásáért, elsősorban a megmaradás (férőhelyek feltöltése, álláshelyek megtartása, iskola megmaradása), másodsorban pedig a könnyen kezelhető, kevesebb problémát jelentő, magasabb szintű eredmények elérését ígérő tanulók megszerzése érdekében (Balázs 2007; Velkey 2013).

Az általános iskolák közötti verseny településen belül alakult ki, amibe legfeljebb a könnyen elérhető települések iskolái léphettek még be. A versenyfeltételeket az önkormányzati iskolák esetében a fenntartó határozta meg:

- a beiskolázási körzetek lehatárolásával,

- az indítható osztályok számának rögzítésével,

- a tagozatok, esetleg városi beiskolázású tagozatos osztályok indításának lehetőségével,

- az infrastrukturális feltételek, eszközök biztosításával,

- az iskola szolgáltatásait rögzítő pedagógiai program elfogadásával, a vonzó képzési elemek (kéttannyelvű képzés, emelt nyelvi óraszámok, művészeti képzés, drámapedagógiai képzés, sporttevékenység, informatikai képzés) engedélyezésével,

- valamint az iskola mozgásterét, lehetőségeit (személyzet kiválasztása, juttatásai) meghatározó, működtetéshez szükséges források biztosításával.

A nem önkormányzati fenntartású iskolákra és a környező települések iskoláira értelemszerüen nem vonatkoztak a helyi versenyfeltételek, így jelenlétük (különösen, ha több ilyen iskola is müködött a településen vagy volt elérhető a közvetlen környezetében) általában még élesebbé tette a versenyt. A fenntartói 
döntéseket az önkormányzati testületek hozták meg. Így abban, hogy e döntések milyen általános versenyfeltételeket alakítottak ki, milyen lehetőségeket biztosítottak az intézményeknek, hogyan viszonyultak az egyházi és magánintézményekhez, illetve a közeli másik településhez, a helyi politikának, a helyi hatalom működési gyakorlatának, a tradícióknak, a helyi érdekcsoportoknak, a kialakult érdekegyeztetési mechanizmusoknak és a helyi elit szemléletének volt meghatározó szerepe. Az ezekből következő sokszínű gyakorlat ellenére valamilyen formában a nagyobb városok mindegyikében megjelentek az elitiskolák és a hátrányos helyzetű vagy cigány tanulókat magasabb arányban ellátó, többnyire peremkerületi szegregált iskolák.

A szervezett magánszolgáltatások szerepe - a fővárost leszámítva - ekkor még mellékes volt. A magas státuszú, tanulás- és tudásorientált, kimagasló teljesítményre képes tanulók képzését, a tehetségek differenciált gondozását képesek voltak színvonalasan ellátni az elitiskolák, köztük a rendhagyó szerkezetủ gimnáziumok. A kiegészítő (fizetős) magánszolgáltatások (nyelviskolák, tehetséggondozó programok, érdeklődési körök), illetve a magántanárok szerepe az egyre élesedő verseny miatt folyamatosan nőtt. E bővülő kiegészítő piaci szolgáltatás azonban szintén a nagyobb városokban összpontosult. A magánforrások bevonása a kiegészítő oktatásba főként az élesebb versenyhelyzetet jelentő rendhagyó szerkezetű, de hagyományos gimnáziumokba történő felvétel időszakában vált intenzívebbé (Velkey 2013).

\section{A szülői szemlélet változása}

E folyamatok alakulásában fontos szerepet játszott a szülői szemlélet már ekkor is érzékelhető változása, mely a verseny helyeslésében, a saját érdek határozott megfogalmazásában és érvényesítésében, a tudatos döntéshozatalban és a tájékozódás igényében, egyúttal a „versenytársadalom” elfogadásában, a társadalmi egyenlőtlenségek, polarizáció tudomásul vételében és a jobb pozíció elérését célzó egyéni stratégiák követésében foglalható össze. Az iskola elkezdésének időszakában ez a „jó iskola” kiválasztását jelenti és a szükséges különórák (idegen nyelv, zene, mozgás, sport, ifjúsági közösség, érdeklődési csoport) iránti keresletben jelenik meg. A jó iskola kiválasztásában az iskola felszereltségének, épületállományának, eszközparkjának, szakmai személyzetének, hírének, elfogadottságának és - nem mellékesen - a tanulók összetételének van meghatározó szerepe. A magas iskolai végzettségű szülők iskolaválasztását már az általános iskolába történő belépéskor is a továbbtanulás esélye motiválja. E szempontok már az iskolakezdés időszakában erősítik a szelektivitást (Radó 2018; Velkey 2013).

A tartósan meglévő többletkapacitások miatt tehát az iskolaválasztás elvi lehetősége széles körben biztosított volt, vagyis az elérhető (elvileg választható) szolgáltatások köre lényegesen kibővült. Ám az elérhetőségben a településközi mozgás (bejárás) reális lehetőségét a társadalmi helyzet érdemben befolyásolhat- 
ta (iskolabusz hiánya, helyközi tömegközlekedés állapota, szülők bejárása, gépkocsi használata stb.), ami már önmagában leszükítette azok körét, akik valóban igénybe is vehették a távolabbi szolgáltatásokat. A szolgáltatások gyorsuló differenciálódása és a szülői szemlélet változása pedig egyrészt hihetetlen módon megnövelte a választási hajlandóságot (amit a szülők nem ritkán szinte kényszerként éltek meg), másrészt a felkínált szolgáltatásokban egyre élesebben érvényesítette a társadalmi helyzettel, származással összefüggő szempontokat. A keresett "gyüjtőiskolákat" (elitiskolákat) lényegében a társadalmi és az iskolai elit jelölte ki, egymással szoros összjátékban. Bár a fenntartó önkormányzatok rendelkeztek (közvetett - korlátozott) eszközökkel a folyamatok befolyásolására, többnyire nem vállalták a helyi elit érdekeivel és a szakmai közvéleménnyel szembeni fellépést.

Összefoglalva megállapítható tehát, hogy a magyarországi közoktatásban az általános iskolai oktatás szintjén már az 1990-es évek elejére egyértelműen megjelent a képességszelekció, mely a továbbiakban egyre szélesebb körben erősödő szociális és etnikai alapú szelekcióval egészült ki. A szelekció alapjává a 2000-es évek közepére a szociális helyzet és az azzal szorosan összefüggő, feltételezett iskolai teljesítmény vált, ami egyszerre jelentette a „megfelelő” tanulók támogatását, és a „nem megfelelők” kiszorítását, kizárását. A felkínált szolgáltatások társadalmi helyzettel összefüggő differenciálódása tehát ekkor már nemcsak érzékelhető, hanem egyre markánsabban és szélesebb körben megfigyelhető jelenség volt, melynek térbeli szerkezete szorosan követte a településszerkezeti jellemzőket és a hátrányos helyzetű lakosság ennek megfelelő térbeli elhelyezkedését.

\section{Állami kezdeményezések a halmozódó problémák kezelésére a 2000-es évek elején}

A halmozódó problémák orvoslásával az önkormányzati rendszer alapproblémáinak kezelhetetlensége és az intézményrendszer önkormányzati fenntartása miatt a kormányzat a 2000-es évek elejétől három irányban is próbálkozott:

- a hátrányok kezelését, kompenzálását segítő integrált oktatás támogatásával,

- a szétaprózott intézményrendszer nagyobb területi egységekbe szervezésével,

- az iskolai szegregációt korlátozó szabályok bevezetésével.

A pedagógiai szakszolgálatok megerősítése, az utazó gyógypedagógiai szolgálatok, gyógytestnevelés rendszerbe illesztése, a korai fejlesztés és diagnosztizálás feltételeinek megteremtése, a hátrányos, halmozottan hátrányos helyzet részletes szabályozása, a tanulói teljesítmények rendszeres mérésének támogatása, az országos mérési rendszer kiépítése önmagában is komoly előrelépést eredményezett. Az SNI-s (sajátos nevelési igényü) tanulók pénzügyi ösztönzőkkel megtámogatott integrált oktatása például igazi sikertörténetnek tekinthető, de érdemben bővült a különböző fogyatékossággal élők integrált oktatásban való részvétele is, még ha e tekintetben lényeges területi különbségek alakultak is ki. 
A szétaprózott intézményrendszer problémáira elsősorban a társulási hajlandóság erősítését segítő pénzügyi ösztönzők (kényszerek) bevezetésével próbáltak választ adni. A társulásban fenntartott intézményeknek járó, létszámhatárhoz kötött normatíva, a többcélú kistérségi társulások szabályozása és normatívája, illetve a konkrét feladatokhoz kapcsolt (szolgáltatások valódi költségeit jobban megközelítö), kötött felhasználású egyedi normatívák számának és szerepének növekedése ${ }^{7}$ adatok szintjén is kimutatható akkumulációs folyamatokat indított el, miközben javultak az infrastrukturális, eszköz- és szakember- ellátottsági mutatók is (Kovács, Koós 2018). Az elemzések a pedagógiai szakszolgálatokban (korai diagnosztizálás, fejlesztés, gyógypedagógia, logopédia, fogyatékossággal élők ellátása) és a kapcsolódó szociális jellegü szolgáltatásokban (étkeztetés, gyermekjóléti szolgálatok) is előrelépésekről számolnak be, ugyanakkor a kistérségeken belüli különbségeket csak kismértékben, vagy nem is csökkentő gyakorlatokra is felhívják a figyelmet (Balázs, Kovács 2012).

Az iskolai szegregáció egyre több helyen előforduló jelenségére válaszul - összhangban a szakmai közvélemény javaslataival (Kertesi, Kézdi 2004) - több deszegregációs szabályt léptettek életbe, melyeknek két típusát különböztethetjük meg:

- az iskolai beiratkozás, felvétel rendjét, a körzeti ellátási kötelezettség részletszabályait, a körzetalakítás elveit, a túljelentkezésre vonatkozó eljárási szabályozásokat,

- illetve a nyolc évfolyamnál kevesebb évfolyammal rendelkező iskolák tanulóinak továbbléptetését garantáló szabályozást.

Az első típusba sorolható szabályok az előforduló szegregációs csatornák lezárását célozták, egyre bonyolultabb és egyre bürokratikusabb eljárásokkal. A második típusba sorolható szabályokra azért volt szükség, mert felgyorsuló iskolai szegregáció esetén, ha a hátrányos helyzetű kistelepülés intézménye nyolc évfolyamnál kevesebbel működött, egyszerüen egyik közeli település nagyobb intézménye sem akarta felvenni a nehezen kezelhető, problémás, többségében roma tanulókat. E kezdeményezések szándékában és a tapasztalatok megítélésében nincs vita a szakemberek között (Havas 2008): egyöntetű vélemény, hogy ott, ahol a helyi társadalom szegregálni akar, és az intézmény irányítása a helyi társadalom által választott - attól újraválasztásában függő - önkormányzati testület hatáskörében van, az amúgy támogatandó deszegregációs szabályokra azok közös kijátszása lesz a válasz, különösen akkor, ha az ellenőrzés, büntetés rendszere nem múködik megfelelően.

\section{Az empirikus kutatás eredményei - az általános iskolai szelekció és szegregáció jellemzői az oktatási rendszer 2011. évi átalakítása előtt és után}

Empirikus kutatásom mintaterületeit úgy választottam ki, hogy az iskolai szelekció és szegregáció fentebb részletezett, vizsgálatot megelőző időszakban jellem- 
zővé váló folyamatait a helyi adottságokat tekintve eltérő típusba sorolható, ám a jelenségcsoport által egyértelműen érintett településeken elemezhessem.

A vizsgált legnagyobb településen (X város) a 2000-es évek első évtizedének közepén öt önkormányzati fenntartású, önálló iskola működött, közülük négy a település központjához viszonylag közel, a város szinte minden részéből jól megközelíthető helyen. A külterületi iskola a város peremzónájában, egy korábban a városhoz csatolt, hagyományos falusias szerkezetü, vegyes lakosságú településrész saját iskolája (volt és ma is az). Ezeken kívül a településen egy közvetlenül a rendszerváltás után alapított egyházi és egy kisebbségi önkormányzat által fenntartott nemzetiségi általános iskola működött. Utóbbiak az önkormányzati iskolákban jellemző 20-25 fös induló osztályokhoz képest lényegesen kisebb létszámú (évfolyamonként egy-egy 12-15 fős) osztályokkal biztosították a felmerülő egyházi, illetve nemzetiségi képzési oktatási igényeket (1. táblázat). Az értelmi képességeikben enyhén akadályozott tanulókat oktató megyei önkormányzati fenntartású iskolában dolgozó szakemberek látták el magas szinten a korai diagnosztizálással, fejlesztéssel, utazó gyógypedagógiai szolgáltatással, gyógytestneveléssel kapcsolatban felmerülő városi igényeket. Az önkormányzati iskolák közül a belvárosban található ( $C$ iskola) német nemzetiségi kisebbségi nyelvet oktató képzéssel, a nagyobb és újabb épületben müködő (D iskola) pedig testnevelési tagozattal rendelkezett. Lényegében ez volt a település iskolarendszerének (helyi általános iskolai oktatási piac) hagyományos és több évtizeden át jellemző felépítése, amit csupán minimális mértékben alakított át a szomszéd kisváros nyolc osztályos egyházi gimnáziuma.

A tanulók létszámának csökkenését kezdetben az indított osztályok számának csökkentésével oldották meg, ám 2006-ban, az országos folyamatokkal összhangban, itt is megtörtént az önkormányzati iskolák egy igazgatási egységbe szervezése. A további létszámcsökkenés miatt - előre tervezett, ütemezett módon - a belvárosi kisebb és régebbi iskolaépületből 2009-ben áthelyezték az osztályokat a nagyobb új épületbe. Közben, 2008-ban az összevont iskola központi épületében (D iskola) a magasabb évfolyamok angol nyelvi képzésének megerősítése mellett felmenő rendszerben elindítottak egy angol kéttannyelvű osztályt, továbbá megtartották a korábban is népszerü testnevelési tagozatot. Mindez azzal a céllal történt, hogy a szomszéd városban működő nyolcosztályos egyházi gimnázium elszívó hatását ellensúlyozzák, és a szintén ott működő, hagyományos szerkezetü két tanítási nyelvü, az X városban is keresett gimnáziumba történő bejutás esélyét növeljék. Az iskolák egy igazgatási egységbe szervezése, majd az egyik épület kivonása a romló pénzügyi, költségvetési helyzet következménye, a kéttannyelvü tagozat pedig a szülők nyomására adott intézményi és önkormányzati válasz volt. Az összevont intézmény kisebb és régebbi épületeiben ( $E$ és $F$ iskolák) így csak normál osztályok indultak (1. táblázat).

2005-ben a város hét iskolája közül az öt önkormányzati fenntartású intézmény körzeti beiskolázással múködött: a német nemzetiségi nyelvet oktató osz- 
tály és a testnevelés tagozat is. Az egyházi és a kisebbségi önkormányzati iskola figyelembe véve az osztályok létszámait is - a tanulók alig 15\%-át vette fel. Az iskolakezdéskor nem, a negyedik osztály után azonban már ekkor is érzékelhető volt a szomszéd város nyolcosztályos gimnáziumának elszívó hatása.

Ebben az időszakban tehát az iskolai szelekció még korlátozott volt a városban az általános iskola megkezdésekor, az etnikai alapú szegregáció a cigány tanulók magas létszáma ellenére sem gyorsult fel. Az iskolák összetétele követte a település belső szerkezetét, a magasabb státuszú családok gyermekeinek aránya a belvárosi, a kisebbségi és az egyházi iskolában volt csak enyhén magasabb az átlagosnál. A cigány tanulók a lakóhelyi elhelyezkedést követve viszonylag egyenletesen oszlottak el az iskolák között (1. táblázat).

Az évtized végére az erősödő szelekciós nyomás és az önkormányzat iskolaszerkezeti változtatásainak hatására jelentősen csökkent a körzeti beiskolázás szerepe. A korábbi 15\%-kal szemben ekkor már a férőhelyek közel 40\%-át tették ki a városi beiskolázást lehetővé tevő tagozatok és a nem önkormányzati iskolák osztályai. Ez a magas arány és a szabad intézményválasztásban érintett szolgáltatások széles köre lényegesen eltér a nemzetközi gyakorlattól. Más országokban is

1. táblázat A cigány tanulók becsült aránya 2005-ben és 2016-ban X város általános iskoláiban Estimated proportion of Gypsy students in 2005 and 2016 in elementary schools in City X.

\begin{tabular}{|c|c|c|c|c|c|}
\hline \multicolumn{3}{|l|}{2005} & \multicolumn{3}{|l|}{2016} \\
\hline Intézmény & 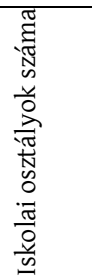 & 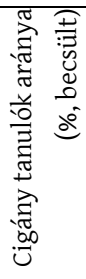 & Intézmény & 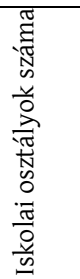 & 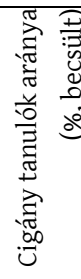 \\
\hline A (egyházi) & $8 / 1$ & 5 & A (egyházi) & $8 / 1$ & 5 \\
\hline B (nemzetiségi) & $8 / 1$ & 10 & B (nemzetiségi) & $8 / 1$ & 15 \\
\hline C (önk. - belváros - német & $8 / 1$ & 10 & C (egyházi - belváros) & $8 / 1$ & 0 \\
\hline \multicolumn{6}{|l|}{ kisebbségi nyelvet oktató) } \\
\hline \multirow[t]{3}{*}{ D (önk. - nagy, új épület) } & $16 / 2$ & 30 & D (állami - német tagozat) & $8 / 1$ & 10 \\
\hline & & & D (állami - angol & $8 / 1$ & 5 \\
\hline & & & kéttannyelvű) & & \\
\hline E (önk. - kisebb épület) & $16 / 2$ & 20 & D/E (állami - kisebb) & $8 / 1$ & 100 \\
\hline F (önk. - régebbi épület) & $16 / 2$ & 15 & D/F (állami - régebbi) & $8 / 1$ & 25 \\
\hline G (önk. - külterületi) & $8 / 1$ & 15 & D/G (állami - külterületi) & $8 / 1$ & 30 \\
\hline Összes osztály/évfolyam & 10 & & Összes osztály/évfolyam & 8 & \\
\hline Első évf./cigány tanulók \% & & 17 & Első évf./cigány tanulók \% & & 28 \\
\hline
\end{tabular}

Forrás: saját adatgyüjtés 
nő már az iskolakezdés időszakában a szabad választás lehetősége, de ez csak az intézmények 10-15\%-át érinti, amelyek magániskolák vagy egyházi szereplők: ${ }^{8} \mathrm{az}$ állami (önkormányzati) intézmények körzeti ellátást nyújtanak, és ezek adják a férőhelyek túlnyomó többségét (Berényi 2018). Természetesen, családi okokból (munkahely, testvér, nagyszülők) előfordulhat, hogy egy gyermek nem a körzeti, hanem másik állami (önkormányzati) iskolába jár, de ennek gyakorisága rendkívül csekély.

A növekvő szelekciós nyomást a helyiek négy okra vezetik vissza:

- a szülői szemlélet változására, amely az egyházi és a kisebbségi önkormányzati iskolák, illetve a tagozatos képzések keresettségének növekedésében mutatkozik meg,

- a szomszéd város nyolcosztályos gimnáziumi képzésének erősödő elszívó hatására,

- a középiskolai továbbtanulási verseny élesedésére és a leszakadástól való félelemre,

- valamint a cigány tanulók arányának növekedésére.

E hivatkozások inkább az elitizálódás gyorsuló folyamatát jelzik, ami ekkor már egyértelműen érzékelhető volt, ám az erősödő szegregációs nyomás ellenére alig változott a cigány tanulók iskolák közötti eloszlása. Ezt az érdekeltek a hátrányok kompenzálását segítő intézkedések eredményességének, a központilag előírt deszegregációs szabályokkal való intézményi azonosulásnak tulajdonítják. Ez utóbbi tényező összhangban van a helyi társadalmi tradíciókkal, amelyek immár évtizedek óta biztosították a cigányok, nemzetiségiek és magyarok, illetve a különböző vallásúak együttélését. A város minden iskolájában működött ugyanis a fejlesztő pedagógia, az utazó gyógypedagógiai szolgálat, elérhetők voltak a szükséges szakemberek, az osztályok csökkenő létszáma ellenére arányosan bontották a csoportokat, így biztosított volt a lehetőség a differenciált oktatásra és a tehetségek gondozására. A szeparációs nyomás sem a tanárok, sem a szülők részéről nem billent át arra a szinte, ami a problémás tanulók már szélesedő körének kizárásához vezetett volna. A helyi elit keresett iskolái tehát nemcsak elérhetőek voltak, de fel is kínálták ezeket a nehezebb szociális helyzetben élő családok gyermekei számára.

2011 után azonban gyökeresen megváltozott az országos helyzet, s ez X városban is felgyorsította az iskolai szelekciót és szegregációt.

- Az új oktatáspolitika kiemelten preferált szolgáltatói lettek az egyházi intézmények. Ez egyrészt az állami iskolák forrásait érdemben meghaladó költségvetési támogatásban (Radó 2019), másrészt a lényegesen nagyobb mozgástérben, helyi döntési szabadságban jelenik meg. Az egyházi iskolák száma és tanulói aránya e politika következményeként már a 2010. évi kormányváltás után érzékelhető növekedésnek indul, s az expanzió azóta is folyik. A korábban kiürített belvárosi iskola épületének felújítása és egy új egyházi iskola létrehozása (2012-ben) e folyamat fontos helyi eredmé- 
nye. Az iskolai férőhelyek száma így a csökkenő tanulói létszám ellenére tovább nőtt, a helyi iskolák közötti, jobb képességű, magasabb státuszú, tudás- és tanulásorientált családok gyermekeiért folyó verseny még élesebb lett. Ez növelte az állami iskolákra nehezedő, tagozatok indítására és a belső szelekció erősítésére irányuló nyomást. A körzeti ellátást nyújtó férőhelyek aránya a városban $40 \%$ alá csökkent, miközben a nem állami intézményfenntartók férőhelyei az országos átlagot közel 10\%-kal meghaladva 25\%-ra növekedtek.

- Az önkormányzati intézmények államosítása után hamar szétestek azok az intézmények közötti szolgáltatási kapcsolatok, melyeknek különleges szerepük volt a halmozódó hátrányok kezelésében. Az iskolai oktatáson kívüli alapszolgáltatásokat elvileg továbbra is térségi szinten, de immár az állami intézménynek számító tankerületek (járás) szervezésében biztosították. Az egyes iskolákban csak a szociális alapellátásokat (gyermekfelügyelet, étkeztetés, iskolaorvos) oldották meg. A gyógytestnevelés, gyógypedagógiai ellátás, korai diagnosztizálás és fejlesztés a szükséges szakszemélyzet biztosításának nehézségei miatt szinte azonnal drasztikusan visszaesett.

- A kötelező óraszám növekedése, a merev tartalmi előírások, az önálló kezdeményezések korlátozása, a túlmunka ellentételezésének megszűnése és a centralizációból következő függőségek nemcsak nehezebbé tették a minőségi pedagógiai munkát, hanem érzékelhető módon erősítették a korábban is meglévő szeparációs nyomást (Radó 2018). Megfelelő külső segítség és eszközök nélkül a pedagógusok képtelenek voltak a halmozódó problémák kezelésére, így partnerré váltak a homogén csoportok szervezésében, az iskolák közötti és iskolán belüli szelekció erősítésében, vagyis a tanulók családi háttér szerinti szétválogatásában.

- Bár hatályban maradtak egyes szegregációellenes rendelkezések, a hátrányos helyzetü és halmozottan hátrányos helyzetű tanulók besorolására vonatkozó szabályok megváltoztatása (Ferge 2017) lényegében az adminisztráció szintjén szüntette meg a szegregációt. $\mathrm{E}$ szabály életbe lépése előtt az E épületben lévő, csak cigány tanulókból álló osztály közel 90\%-a halmozottan hátrányos helyzetű volt. A szabályok változása után ugyanabban az osztályban, ugyanazon gyerekek közül kevesebb, mint 50\% lett halmozottan hátrányos helyzetű, vagyis adminisztratív értelemben az osztály nem szegregált, így nincs is szükség szegregáció elleni intézkedésekre és a halmozott hátrányok többleterőforrásokat igénylő kezelésére.

Mindezek hatására a két egyházi iskola, illetve az állami iskola német tagozata és angol kéttannyelvű képzése váltak a helyi társadalmi, politikai és gazdasági elit iskoláivá. Ezekbe az osztályokba lényegében ma már nem juthat be hátrányos helyzetü, alacsony státuszú és (különösen) cigány tanuló, számukra ezek az iskolák, bár elérhetőek, mégsem jelentenek felkínált képzést. A kompe- 
tenciamérések alapján 2010 előtt a belvárosi és a nemzetiségi iskola teljesítménye volt a legmagasabb a városban: ezek az iskolák a hatodikos és nyolcadikos matematika és szövegértési feladatokban is az ország legjobb általános iskolái között (felső 5\%) foglaltak helyet. 2012 után (ekkor lettek hatodikosok az iskolák átszervezésekor belépő tanulók) eredményeik érzékelhetően romlottak, majd az utóbbi néhány évben a nemzetiségi iskolában enyhén javuló tendenciát mutatnak. Ezt magyarázhatja, hogy a nemzetiségi iskola a gyorsuló elkülönülés időszakában a jobb anyagi helyzetű cigány családok menekülő útjává vált. Az átlagos cigány tanulók számára az elérhető iskolák közül elvileg választhatók (felkínáltak) maradtak a D/E-F-G állami fenntartású intézmények, melyek közül - az elérhetőség miatt - a közelben lakókat leszámítva kiesik a külterületi (D/G) és a város másik felében lévő $D / F$ iskola. Utóbbi körzetében hagyományosan alacsonyabb a cigány tanulók aránya. A városban élő nehezebb helyzetü diákok és a cigány tanulók többsége számára az E iskola választása a realitás. Ide szorul vissza a cigány tanulók többsége, leszámítva azokat, akik kockáztatva az erősödő társadalmi elóítéletekből következő beilleszkedési nehézségeket, menekülési utakat keresnek (korlátozottan látnak más lehetőségeket), például a B (nemzetiségi) iskolát (1. táblázat).

Napjainkban a legjobb kompetenciamérési eredményeket a 2012-ben alakult egyházi iskola tanulói produkálják (különösen matematikából). Ez nemcsak a szülői háttérnek, hanem a pedagógiai munkának is köszönhető. Mind a hozzáadott érték, mind a családi háttérindex alapján kimondottan jól teljesít az iskola. A hagyományos egyházi iskolában az angol és a német képzés országos összevetésben az átlagosnál kissé jobb, az idősorokat tekintve enyhén javuló eredményeket mutat. A cigány tanulók intézményévé váló iskola 2012-2013-ig az átlaghoz illeszkedő, majd érzékelhetően romló eredményeket mutat. A méréseken résztvevő tanulók alacsony száma miatt a családi háttérindex adatok nem állnak rendelkezésre. A külterületi és a régebbi épületben működő, körzeti feladatokat ellátó iskolák eredményei szintén enyhén romló tendenciát mutatnak, a jelen felé közeledve - illeszkedve az országos adatokhoz - a családok szociális helyzetéhez képest is alulteljesítenek.

A vizsgált másik (Y) városban hagyományosan három általános iskola működött. Az 1990-es években a belvárosban található modern, jól felszerelt iskola a megyei tanulmányi versenyek egyik legsikeresebb kisvárosi intézménye volt. A másik két iskola a város peremzónájában helyezkedett el. Az egyik az ipartelep közelében: ide jártak az ipari (élelmiszeripari nagyüzem) munkások gyermekei. A másik pedig a cigányok által nagyobb arányban lakott övezetben elhelyezkedő régi iskola volt. A településen sem egyházi, sem nemzetiségi iskola nem jött létre és jelenleg sem müködik.

X városhoz hasonlóan a 2000-es évek első évtizedének közepéig az iskolák tanulói - a körzeti ellátás logikáját követve - a lakóhelyükhöz legközelebbi iskolát választották. Az iskolák társadalmi összetétele követte a lakosság térbeli elhelyezkedését: a magasabb státuszú családok gyermekei a belső iskolába, az 
alacsonyabb státuszú magyar gyerekek az ipartelepibe, a peremzónában lakó cigány tanulók pedig a legkevésbé felszerelt régi iskolába jártak nagyobb arányban. A belső iskola minden évfolyamon meglévő két osztályát az akkor elfogadott gyakorlat szerint a negyedik osztály elvégzése után a tanulmányi eredmények alapján - homogén csoportok kialakítására törekedve - válogatták szét, sorolták be a felsős osztályokba. A kompetenciamérések egyértelműen mutatják az eredmények osztályok szerinti lényeges eltérését. A belső iskola jobb osztálya a kisvárosi átlagot lényegesen meghaladó, a másik pedig az ipartelepi iskola osztályaival együtt átlagos szintű eredményeket mutatott.

2006 után ebben a városban is megtörtént az iskolák egy intézménybe történő összevonása, majd második lépésként a régi épület kivonása is. Ezt a gyermeklétszám csökkenésére, a régi épület felújítási kényszerére és az ekkor már hatályba lépő deszegregációs szabályokra hivatkozva lépte meg az önkormányzat. A régi iskola épületének kiürítése egy ütemben történt, a korábban három párhuzamos osztállyal rendelkező belső iskola két működő normál osztálya mellé helyezték el a régi iskola egyben tartott osztályait. Külön csoportban maradtak a belső iskola kis létszámú, értelmi képességeikben enyhén akadályozott tanulói. Az összevonás utáni, 2008-2010. évi kompetenciamérések alapján a régi iskola áthelyezett, belső iskola harmadik, leggyengébb normál osztályaként müködő csoportja hatodikos matematikából - messze elmaradva az országos átlagtól - a legjobb osztály átlagának 57, szövegértésben 63\%-át érte el.

Az összevonás és épületkivonás a belső iskolába bekerülő jelentős számú cigány tanuló miatt gyorsan kifejlődő láncreakciót indított el. A létszámadatok alapján az összevonást követően szinte azonnal elindult a belső iskola felső tagozatán egy fokozatos elszivárgás, egyrészt az ipartelepi iskola felső tagozatának alacsonyabb létszámú osztályaiba, másrészt a közeli nagyváros nyolcosztályos egyházi gimnáziumába. Ezzel párhuzamosan, a negyedik osztály után is egyre nagyobb arányban léptek ki a tanulók a környező városokban elérhető nyolcosztályos gimnáziumokat keresve. Az első osztályos beiskolázáskor a város belső területeiről többen választották ekkor már az ipartelepi iskolát és a könnyen elérhető nagyváros jól szervezett, többletkapacitásokkal rendelkező általános iskoláit. Míg tehát korábban a helyi általános iskolai oktatási piacra az első osztályos beiskolázáskor egyáltalán nem volt hatása a környező települések szolgáltatásainak és az elérhető nyolcosztályos gimnáziumi képzések is csak keveseket szívtak el a városból, ez a helyzet az összevonás után drasztikusan megváltozott. Miután a város iskolái leértékelődtek a helyi elit szemében, az érintettek többletköltséget, kényelmetlenséget vállalva egy szélesebb oktatási piacon kerestek maguk számára megfelelő szolgáltatást.

A kevesebb belépő és az elszivárgók miatt a belső iskola osztályait elkezdték átszervezni, ami tovább gyorsította a „kimenekülést” - ahogy az iskola egyik dolgozója megfogalmazta a jelenséget. A helyiek szerint napjainkban legalább két busznyi általános iskolás korú tanuló jár be minden nap a szomszéd városba. 
A kompetenciamérések adatai egyértelműen visszaigazolják az iskolák közötti vándorlást és a gyorsuló szegregációt. A belső iskola mára megmaradó két párhuzamos normál osztálya a kisebb létszámok ellenére (15-20 tanuló) az utóbbi három évben a hatodikos matematikamérések szerint az ország leggyengébbjei között van, közel 300 ponttal elmaradva az országos átlagtól és 200 ponttal elmaradva az ipartelepi iskola átlagától.

A helyi szakemberek véleménye szerint súlyos hiba volt a régi épület kivonása. A szakirodalomban részletesen leírt és elemzett „hódmezővásárhelyi modell" (Szücs 2018) a cigányok magasabb aránya és a kevesebb iskolai osztály miatt nem is működhetett a településen. A lakosság elhelyezkedését követő szegregációt tudomásul véve, a pedagógiai munka megerősítésével, eszközök és szakemberek biztosításával kellett volna a régi iskolában halmozódó problémákat kezelni, amivel elkerülhető lett volna a város iskolarendszerének összeomlása és egyre többek menekülése a nagyvárosba.

Véleményük szerint a kedvezőtlen folyamatokat elindító döntés politikai alapú volt és kívülről kezdeményezték, úgy érzik, hogy az iskolák államosítása immár lehetetlenné teszi a szélesen értelmezett helyi közösség érdekeinek képviseletét. „Az állam elvitte az iskolát és ezzel átvette a felelösséget is, majd azt mondta, hogy mindenki boldoguljon, ahogy tud. Aki tud, boldogul is, aki meg nem tud, az marad..." - mondta egy elkeseredett iskolai dolgozó. Lényegében tehát a helyi szolgáltatások leromlásával, szétesésével a jó érdekérvényesítő képességekkel rendelkezö, mobil, magas státuszú családok az elérhetőség kibővítésével, egy szélesebb, nagyobb oktatási piac értelmezésével teremtették meg maguknak a megfelelő (felkínált) szolgáltatásokat. Ez a lehetőség azok számára, akik elől sokan a szomszéd városba menekülnek, nem biztosított, nekik nem kínálták fel. ők választhatják korlátozott számban az ipartelepi iskolát, a többi pedig marad, visszaszorul a számukra egyedüliként adott belvárosiba.

Az iskolai szelekció és szegregáció drámai gyorsulásában minden érintett fontos szerepet tulajdonít a tanárok leterheltségének, az elismerés hiányának és a pedagógiai szakszolgálati tevékenység háttérbe szorulásának. A helyiek véleménye szerint a társadalmi polarizáció erősödése szinte automatikusan vonja maga után a szegregációt, a tanulók iskolai csoportokba szervez(ődé)ését családi hátterük szerint, különösen ott, ahol a cigányság aránya magasabb és társadalmi integrációjuk is nehézségekbe ütközik.

A vizsgált harmadik település (Z) története az előbbiektől merőben eltérő képet mutat. Itt egyetlen iskola található, amelyben minden évfolyamon egy kis létszámú osztály működik. A település földrajzi elhelyezkedése és közlekedési kapcsolatai miatt csak nehezen érhető el valamely nagyobb, magasabb szintü szolgáltatást nyújtó város. A középiskolába járó diákokon kívül munka miatt naponta alig egy tucatnyi ember hagyja el a települést, így szülőkkel együtt ingázó tanulók sincsenek. Minden helyben lakó gyermek a helyi iskolába jár, a cigányok magas települési aránya miatt az osztályok mindegyike cigány többségü, az intéz- 
mény kívülről nézve szegregált, ún. gettóiskola. A helyi (elérhető) oktatási szolgáltatási piac tehát lényegében egyetlen iskolát jelent: alternatívaként a szomszéd falvak kisebb iskolái jöhetnének szóba, ám ezek egyikének sem kedvezőbbek a tárgyi adottságai. Egy kisebb közeli falu iskolája lehetne vonzó, hiszen ott egyetlen cigány tanuló sincs, mégsem keresik a helyiek. Lényegében az elérhető szolgáltatások beszükülése hozta létre azt a helyzetet, amelyben a helyi közösség számára a megmaradás egyik kiemelt szimbóluma az iskola lett. A helyi közösség ezért az önkormányzati fenntartás időszakában és azt követően is erőn felül áldozott az iskolára: mindenki szívügyének tekintette az iskola megmaradását, müködését, fejlődését. Ennek eredményeként - EU-források bevonásával - néhány éve sikerült teljesen felújítani az épületet és építeni egy új tornatermet, mellyel az infrastruktúra és eszközpark valóban eléri a napjainkban joggal elvárhatót. Az iskola tanári kara helyben él, az önkormányzati vezetők, helyi gazdák gyermekei szintén ide járatják gyerekeiket, miként a közmunkából élők, vagy a szociálisan segélyezettek is.

A kompetenciamérés adatai szerint 2008-tól napjainkig a tanulók hatodikos matematika és szövegértési eredményei kisebb hullámzásokkal mindvégig a községi átlag szintjén álltak. A nyolcadikos eredmények szövegértésből továbbra is a községek átlaga körül alakulnak, matematikából azonban több évfolyam esetében is meghaladják azokat, mutatva az összefogás, odafigyelés eredményét, tovább erősítve a fejlődés, előrelépés lehetőségét.

\section{Elszabaduló egyenlőtlenségek, újratermelődő területi és társadalmi hátrányok 2011 után a hazai alapfokú iskolarendszerben - összefoglalás}

Az oktatási rendszer 2011 utáni radikális átalakítása több ok miatt is lényegesen gyorsította az iskolai szelekciót és szegregációt. Az új állami oktatáspolitika nyíltan preferált intézményei az egyházi iskolák lettek. Ez egyrészt az állami iskolák forrásait érdemben meghaladó költségvetési támogatásban, másrészt a lényegesen nagyobb mozgástérben, helyi döntési szabadságban jelenik meg. Az egyházi iskolákba járó tanulók száma országos szinten 2006-2016 között több mint kétszeresére növekedett, az általános iskolák esetében részarányuk a 2000. évi 4,5\% és a 2009. évi 8\% után mára megközelíti a 15\%-ot. Az állami iskolák mellett működo,, körzeti ellátási teher alól mentesülő egyházi iskolák számának gyors növekedése nemcsak önmagában, hanem az állami iskolákban jelentkező szelekciós nyomás miatt is már az általános iskola megkezdésekor érdemben gyorsította az iskolai szelekciót. A jelentkezők közötti válogatás „szabadságával” rendelkező iskolák (férőhelyek) számának érdemi bővülése szélesre nyitotta annak lehetőségét, hogy az elérhető szolgáltatásokon belül elkülönülhessenek a különböző társadalmi csoportba tartozó, eltérő társadalmi helyzetü és etnikumú családok számára felkínált szolgáltatások. 
Az önkormányzati intézmények államosítása az iskoláztatás megszervezését egyértelmü állami feladatként definiálta, így mentesítette a helyi politikai, társadalmi, gazdasági elitet a helyi oktatási rendszer kiegyensúlyozott, minden helyi érdeket figyelembe vevő megszervezésének felelőssége alól. A helyi elit így az iskoláztatással kapcsolatos érdekérvényesítő (közéleti) tevékenysége során szabadabban koncentrálhat a saját érdek érvényesítésére, a színvonalában, tartalmában neki tetsző intézményi szolgáltatások kikényszerítésére, majd annak kisajátítására. Ez a helyi viszonyok, tradíciók alapján jelentheti az egyházi iskolai képzés megszervezésének támogatását, tagozatok indítását az állami iskolákban (X település), vagy jobb szolgáltatást nyújtó képzési helyek választását egy másik településen ( $Y$ település) az iskola megkezdésekor vagy a negyedik, hatodik évfolyam elvégzése után. Persze, egyúttal elvileg lehetővé teszi a helyi iskola (iskolák) minden helyben élő érdekeit szolgáló fejlesztését is, tovább erősítve a helyi közösség egészéért ( $\mathrm{Z}$ település) vállalt felelősséget. Az államosítás utáni időszakban tehát rendhagyó módon nem beszükült, hanem kiszélesedett a helyi elit lehetősége az önérdek megfogalmazására és érvényesítésére a helyi oktatási rendszer alakításában.

Az elérhető szolgáltatások gyorsuló differenciálódása kutatási tapasztalataim szerint a társadalmi helyzettől, illetve az iskoláztatáshoz, tudáshoz, tanuláshoz való viszonyulástól függően eltérő döntési lehetőségeket és válaszokat eredményez. A jó érdekérvényesítő, magas státuszú csoportok igyekeznek a maguk számára megszervezni vagy más településen elérni a jó szolgáltatásokat. Ez együtt jár a családok társadalmi háttér szerinti szétválogatásával, az elitizálódás erősödésével, ami magába foglalja az alacsonyabb státuszúak kizárását, bejutásuk korlátozását ezekben a magasabb státuszúak számára felkínált „kiválasztott” intézményekben. A tudás és tanulás iránt kevésbé érzékeny szülők jellemzően továbbra is a körzeti iskolát preferálják, ${ }^{9}$ ha azonban annak társadalmi összetételét, felszereltségét már problémásnak vagy veszélyesnek vélik, menekülési utakat keresnek, és az elit által kevésbé preferált, számukra is felkínált, számukra is választható iskolákba viszik gyermekeiket (Hricsovinyi, Józsa 2018). Az elitizálódó és menekülési utat jelentő iskolák értelemszerüen mereven bezáródnak a legrosszabb helyzetű családok gyermekei előtt, akik így visszaszorulnak a legrosszabb körzeti iskolákba. Mindez tovább gyorsítja a szolgáltatás differenciálódását és a társadalmi háttér szerint osztja el az iskolák (telephelyek, osztályok) között a tanulókat. Ez a folyamat különösen érzékenyen reagál az etnikai különbségekre: ahol nagy számban élnek cigányok, ez élesedő társadalmi polarizációt eredményez, a folyamat sokkal gyorsabb és drámai hatású.

A kötelező óraszám növekedése, a merev tartalmi előírások, az önálló kezdeményezések korlátozása, a túlmunka ellentételezésének megszűnése és a centralizációból következő függőségek nemcsak nehezebbé teszik a minőségi pedagógiai munkát, hanem erősítik az ún. szeparációs nyomást is. Az iskolák megfelelő eszközök és segítő szakemberek nélkül partnerré válnak a homogén csoportok szervezésében, a problémák elkerülésében, „lerúgásában”, például a „ne buktas- 
suk meg, mert akkor itt marad a nyakunkon" érvelés alapján. Ugyanazok a tanárok, akik évekkel korábban elkötelezetten képviselték az integrált oktatást és a szegregáció elleni fellépést, mára belefáradtak a mindennapi küzdelembe és fásultan veszik tudomásul, vagy hallgatólagosan támogatják is a szelekciót és a szegregációt.

A korábbi állami oktatásirányítás szemérmes integrációpárti, a spontán szegregációt adminisztratív eszközökkel korlátozni akaró megközelítését a társadalmi polarizációt természetesnek tekintő, az iskolai szelekciót és a szegregációt tudomásul vevő álláspont váltotta fel. Mi sem bizonyítja ezt szemléletesebben, mint a hátrányos helyzetủ és halmozottan hátrányos helyzetü tanulók besorolásának fentebb hivatkozott megváltoztatása és a hátrányok kompenzálását szolgáló, korábban kiépült ellátási rendszerek szétesése, lassú eróziója. Az állam ezzel lemondott arról a korábban hangoztatott oktatáspolitikai célról, amely a társadalomban lévő tudáspotenciál minél szélesebb körü kiteljesítését tartotta fő feladatának, vagyis arról, hogy „lehetőleg mindenkit eljuttasson oda (arra a szintre), ahova a képességei szerint eljuttatható". Azt a megközelítést tehát, amely az állam felelősségét hangsúlyozza minden tanuló szervezett intézményes oktatásában, a megfogalmazott oktatáspolitikai célok és tettek mögött meghúzódó azon szemlélet váltotta föl, mely a szülő és a család felelősségét hangsúlyozza a gyermek taníttatásának megszervezésében. Így azon családok számára, akik igénylik a tudást, akik fontosnak tartják a tanulást, biztosítja az ehhez szükséges „királyi utakat" (felkínált magasabb szintű szolgáltatások). Engedi az iskolai szelekciót (a gyerekek társadalmi háttér szerinti szétválogatását) és erőforrásokat csoportosít át az „igényesebb” szülők iskolái számára. Akik azonban ezt nem igénylik, megkapják a romló színvonalú normál állami, akiknek pedig úgyis mindegy, a sehová sem vezető szegregált állami oktatást. Az elérhető szolgáltatások differenciált felkínálása (és egyúttal korlátozása) teremti meg ennek lehetőségét, melynek konkrét „tartalommal” történő megtöltésében, helyi megjelenésében a fentebb leírtak alapján meghatározó szerepe van a helyi elitnek és az iskoláknak.

Az állami és egyházi intézményeket is érintő egységesítés és szük mozgásteret adó tartalomszabályozás, továbbá a teljes közfinanszírozott rendszert sújtó kedvezőtlen munkafeltételek (magas kötelező óraszám, alacsony bérszínvonal, hiányzó vagy nagyon szűk körű segítő személyzet, bürokratikus előmeneteli rendszer) az elmúlt időszakban érzékelhetően megnövelték a keresletet az alternatív program szerint működő magániskolák iránt. A magánintézmények száma a fővárosban és a nagyobb városokban gyors növekedésnek indult, és immár a közepes vagy kisebb városokban is megjelentek a magántanulói státuszt kihasználó alternatív, magánforrásokból finanszírozott, gyakran informális intézmények. A közfinanszírozott oktatás egyre szélesebb körben jelentkező zavarai tehát a piaci szolgáltatások fokozatos bővülését eredményezik, ami a felsőoktatási verseny élesedése miatt válaszra kényszeríti a teljes rendszert. Tovább gyorsul például a rendhagyó szerkezetü gimnáziumok differenciálódása és a kimagaslóan jó iskolákért folyó verseny. A ver- 
senyben pedig csak azok tudnak sikeresen részt venni, akik túllépnek a közfinanszírozott oktatás által nyújtott szolgáltatásokon, igénybe veszik a piaci kiegészítő szolgáltatásokat, vagyis az ehhez szükséges anyagi erőforrásokkal rendelkező családok. Ha csak a lejtő két végét emeljük ki: az államosítás jelenlegi formája az államon túli, piaci megoldások irányába löki a tudás és tanulás iránt érzékeny, jó jövedelmi helyzetű családokat, illetve a továbblépés esélyétől is megfosztja a hátrányos helyzetű térségekben élő alacsony státuszú családok gyermekeit.

\section{Jegyzetek}

1 A rendszerváltáskor az önállóságukat visszanyerő volt társközségek, kisebb települések, helyi közösségek némelyike új iskolák létesítésére is vállalkozott.

2 Az önkormányzatok ekkor a kétlépcsős iskolabezárás gyakorlatát alkalmazták: pénzügyi okokra hivatkozva első lépésben összevonták az intézményeket, csökkentve az adminisztratív költségeket és a fejlesztési, felújítási kényszereket, optimalizálva az infrastruktúra használatát (tornaterem, szaktantermek), majd második lépésben kivonták az ellátásból a lerobbant, kevésbé keresett, egyéb célra is hasznosítható épületeket.

3 Az egyházi fenntartású általános iskolába járó tanulók aránya 2002-2010 között 3,9\%-ról 6,3\%-ra nőtt.

4 Racionálisan szervezett iskolai osztályok esetén az 1990-es évek közepén a normatíva 80-85\%-ban fedte le a valós költségeket, mely arányszám folyamatosan csökkenő tendenciát mutatva a válsághoz kapcsolódó megszorítások eredményeként 2009-re 45\%-ra csökkent.

5 Az általános iskolai korosztály esetében a lakóhelyen kívüli iskolát választó szülők egyértelmüen a napi ingázással elérhető iskolákat preferálják a kollégiumi elhelyezéssel szemben.

6 A jobb ellátásért folyó, szülők közötti, illetve a megmaradásért (gyermekekért) zajló intézmények közötti verseny a nagyobb városokban már az óvodák szintjén is egyértelműen kimutatható (Velkey 2013).

7 Az 1995. évi tizenhatról 2004-re hatvan fölé emelkedett a közoktatási normatívák száma (Varga 2008), ami nemcsak a rendszer bonyolultságát növelte, hanem tovább erősítette a pénzügyi szempontok fontosságát az iskolafenntartók oktatási döntéseiben.

8 Ezek a körzeti ellátási kötelezettséggel terhelt közfinanszírozott állami (önkormányzati) iskolákkal szemben tandíjat számolnak fel, vagy ha közfinanszírozásban részesülnek, akkor (vallási értelemben) elkötelezett képzést nyújtanak, tehát az ideológiai, vallási értelemben semleges állami szolgáltatás kiegészítéseként értelmezhetők.

9 Miért is keresnének mást, ha nem tartják a tanulást annyira fontosnak...

\section{Köszönetnyilvánítás}

Ezúton is szeretném megköszönni Velkeyné Palócz Erikának a kompetenciamérések adatainak összegyűjtésében és elemzésében nyújtott segítségét, továbbá a különszám szerkesztőinek (Timár Juditnak és Nagy Erikának), illetve lektoraimnak az értékes észrevételeket és javaslatokat.

A tanulmányt megalapozó kutatások részben az NKFI-6 (OTKA) 109269. számú, „Az állam strukturális átalakulásaira adott intézményi és egyéni válaszok különböző földrajzi kontextusokban" című kutatás (2013-2018), részben pedig NKFI_(OTKA)-6-K-125110 „A szakképzés munkapiaci illeszkedésének területi és ágazati jellemzői, kiemelt figyelemmel a periférikus térségekre és a korai iskolaelhagyás problémájára" címü kutatás (2017-2021) keretében folytak. 


\section{Irodalom}

Balázs É. (2007): A versenyképesség területi és társadalmi összefüggései. In: Simon M., Kósa B. (szerk.): Közoktatás és versenyképesség. Hatékonyság és minőség: aktuális kérdések a hazai közoktatásban. Oktatáskutató és Fejlesztő Intézet, Budapest, 29-43.

Balázs É., Kovács K. (szerk.) (2012): Többcélú küzdelem - Helyzetképek a kistérségi oktatásról. Oktatáskutató és Fejlesztő Intézet, Budapest

Berényi E. (2018): Szabad választás és szegregáció. In: Fejes J. B., Szűcs N. (szerk.): Én vétkem. Helyzetkép az oktatási szegregációról. Motiváció Oktatási Egyesület, Szeged, 57-66.

Berki M. (2014): Az egykori ipari területek funkcióváltásának példái Budapesten. A posztszocialista kontextus és a földrajzi lépték szerepe az átalakulásban. PhD-értekezés. ELTE TTK Földtudományi Doktori Iskola, Budapest

Berki M. (2015): A térbeliség trialektikája. Tér és Társadalom, 2., 3-18. https://doi.org/10.17649/TET. 29.2.2658

Carman, T. (1999): The body in Husserl and Merleau-Ponty. Philosophical Topics, 2., 205-226. https:// doi.org/10.5840/philtopics199927210

Csapó B. (2008): A magyar iskolarendszer adaptációs problémái. A tudás minősége. In: Fazekas K. (szerk.): Közoktatás, iskolai tudás és munkapiaci siker. MTA Közgazdaságtudományi Intézet, Budapest, 113-130.

Fejes J. B., Szűcs N. (szerk.) (2018): Én vétkem. Helyzetkép az oktatási szegregációról. Motiváció Oktatáskutató Egyesület, Szeged

Ferge Zs. (2017): Magyar társadalom- és szociálpolitika (1990-2015). Osiris Kiadó, Budapest

Forray R. K. (1986): Általános iskolai sikertelenség aprófalvas térségekben. In: Forray R. K., Kozma T. (szerk.): Oktatásökológia. Oktatáskutató Intézet, Budapest, 307-328.

Hadjimichalis, C., Hudson, R. (2014): Contemporary Crisis Across Europe and the Crisis of Regional Development Theories. Regional Studies, 1., 208-218. https://doi.org/10.1080/00343404.2013.834044

Hajdu T., Hermann Z., Horn D., Varga J. (2016): A közoktatás indikátorrendszere 2015. MTA KRTK, Budapest

Havas G. (2008): Esélyegyenlőség, deszegregáció. In: Fazekas K., Köllő J., Varga J. (szerk.): Zöld könyv a magyar közoktatás megújitásáért. ECOSTAT, Budapest, 121-138.

Havas G., Kemény I., Liskó I. (2002): Cigány gyerekek az általános iskolában. Oktatáskutató Intézet, Új Mandátum Kiadó, Budapest

Havas G., Liskó I. (2006): Óvodától a szakmáig. Oktatáskutató Intézet, Új Mandátum Kiadó, Budapest

Hermann Z. (2008): Hogyan értelmezzük az iskolarendszer minőségi mutatóit nemzetközi összehasonlításban? In: Fazekas K. (szerk.): Közoktatás, iskolai tudás és munkapiaci siker. MTA Közgazdaságtudományi Intézet, Budapest, 43-72.

Hricsovinyi J., Józsa K. (2018): Iskolaválasztás és szelekció. In: Fejes J., Szűcs N. (szerk.): Én vétkem. Helyzetkép az oktatási szegregációról. Motiváció Oktatási Egyesület, Szeged, 129-146.

Hudson, R. (2016): Rising Powers and the Drivers of Uneven Global Development. Area Development and Policy, 3., 279-94. https://doi.org/10.1080/23792949.2016.1227271

Kertesi G., Kézdi G. (2004): Általános iskolai szegregáció. Okok és következmények. Budapesti Corvinus Egyetem, MTA Közgazdaságtudományi Intézet, . https://mek.oszk.hu/02500/02510/02510.pdf (Letöltés: 2019. október 22.) (Budapesti Munkagazdaságtani Füzetek 7.)

Kertesi G., Kézdi G. (2014): Iskolai szegregáció, szabad iskolaválasztás és helyi oktatáspolitika 100 magyar városban. http://www.econ.core.hu/file/download/bwp/bwp1406.pdf (Letöltés: 2019. október 22.) (Budapesti Munkagazdaságtani Füzetek; 6.)

Kovai M., Neumann E. (2015): Hova lett az egyenlősítő közoktatás? Educatio 4., 65-78.

Kovács K., Koós B. (2018): A település-állomány jólléti pozíciójának mintázatai és azok változása 1990-2016. Észak-magyarországi Stratégiai Füzetek, 3., 13-30.

Ladányi J. (2009): A burkolt szelekciótól a nyilt diszkriminációig. Párbeszéd a vidékért. MTA Történettudományi Intézet, MTA Társadalomkutató Intézet, Budapest 
Lang, T., Henn, S., Ehrlich, K., Sgibnev, W. (2015): Understanding New Geographies of Central and Eastern Europe. In: Lang, T, Henn, S., Ehrlich, K., Sgibnev, W (eds.): Understanding Geographies of Polarization and Peripheralization. Perspectives from Central and Eastern Europe and Beyond. Palgrave Macmillan UK

Lefebvre, H. (1991): The production of space. Blackwell, Oxford

Peck, J. (2016): Macroeconomic geographies. Area Development and Policy, 3., 305-322. https://doi.org/ 10.1080/23792949.2016.1237263

Radó P. (2018): A közoktatás szelektivitása, mint a roma szegregáció általános kontextusa In: Fejes J. B., Szücs N. (szerk.): Én vétkem. Helyzetkép az oktatási szegregációról. Motiváció Oktatási Egyesület, Szeged, 31-56.

Radó P. (2019): Market reforms in the Hungarian school system: impact of changes in the ownership structure. NESET ad hoc question No. 2/2019. https://nesetweb.eu/wp-content/uploads/2019/07/NESET_AHQ2_2019_Market-reforms-in-the-Hungarian-school-system_Impact-of-changes-intheownership-structure-2.pdf (Letöltés: 2019. október 14.)

Soja, E. (1996): Thirdspace. Journeys to Los Angeles and other real and imagined places. Blackwell, Oxford Soja, E. (2010): Seeking Spatial Justice. University of Minnesota Press, Minneapolis

Szűcs N. (2018): A hódmezővásárhelyi deszegregációs intézkedés: az oktatási rendszer esélyegyenlőség-fókuszú komplex átszervezése In: Fejes J. B., Szűcs N. (szerk.): Én vétkem. Helyzetkép az oktatási szegregációról. Motiváció Oktatási Egyesület, Szeged, 343-354.

Varga J. (2008): Az iskolaügy intézményrendszere, finanszírozása. In: Fazekas K., Köllő J., Varga J. (szerk.): Zöld könyv a magyar közoktatás megújitásáért. ECOSTAT, Budapest, 235-258.

Velkey G. (2013): Dinamikus egyensúlytalanság. A hazai közoktatási rendszer szétesése, felforgatása és a konszolidáció esélye. MTA KRTK RKI, Budapest, Pécs, Békéscsaba

Zolnay, J. (2018): Commuting to segregation. The role of pupil commuting in a Hungarian city: between school segregation and inequality. Review of Sociology, 4., 133-151. 